\title{
Development of cutoff-related knickpoints during early evolution of submarine channels
}

\author{
Zoltán Sylvester ${ }^{* 1}$ and Jacob Covault ${ }^{\dagger 2}$ \\ ${ }^{1}$ Chevron Energy Technology Company, Houston, Texas \\ ${ }^{2}$ Bureau of Economic Geology, The University of Texas at Austin, Austin, Texas
}

Preprint of Zoltán Sylvester, Jacob A. Covault (2016), Development of cutoff-related knickpoints during early evolution of submarine channels. Geology; 44 (10): 835-838. doi/https://doi.org/10.1130/G38397.1

\begin{abstract}
Submarine channels are often thought of as having relatively simple geometries, with significant alongchannel morphologic and stratigraphic continuity. Using high-resolution seismic reflection data from offshore Angola and a kinematic model of channel evolution, we present evidence that channels on the seafloor can develop slope variability as a result of meander cutoff events. When cutoffs develop, the shortened flow paths produce locally steep gradients, thus initiating knickpoints. Waves of knickpoint retreat and the related channel incision explain the occurrence of terraces and associated remnant channel deposits above the youngest channel thalweg. The simple processes of meander cutoff followed by knickpoint retreat are intrinsic to submarine channels and result in significant morphologic variability, erosion, and stratigraphic complexity, without any external forcing. These insights highlight the early evolution of submarine channels, a phase with a record that is commonly fragmented or completely absent as a result of subsequent erosion, and allow a better understanding of the autogenic controls on deep-marine stratigraphy.
\end{abstract}

\section{Introduction}

Submarine channels are conduits through which sediment and organic matter are transported to deepsea basins by sediment gravity flows, and they are important components of the stratigraphic record of environmental change (Clift and Gaedicke, 2002; Covault et al., 2010). Submarine channel deposits also form important petroleum reservoirs. A clear understanding of the controls and processes that create submarine channels remains elusive, because there are few direct measurements of turbidity currents that shape them and limited documentation of their longer term morphodynamic evolution (Talling et al., 2015). Instances of highly sinuous channels are especially puzzling where, in contrast with rivers, there is no obvious evidence of bend expansion and sinuosity development (e.g., Kolla et al., 2001; Deptuck et al., 2012, their figure 13b). In addition, submarine channels are often assumed to have relatively smooth profiles and axial deposits with significant downslope continuity (e.g., McHargue et al., 2011; Sylvester et al., 2011; although, see also Snedden, 2013), unless avulsions (Pirmez et al., 2000) or slope deformation affect them. Here we show how channels with large slope variability and limited inner bank deposition can form without any external influence, by combining interpretations of submarine channel evolution from seismic reflection data of the subsurface offshore West Africa with a numerical model of channel meandering and incision.

\footnotetext{
*Presently at the Bureau of Economic Geology, The University of Texas at Austin, zoltan.sylvester@beg.utexas.edu

$\dagger$ jake.covault@beg.utexas.edu
} 


\section{Data and Methods}

\section{Seismic Reflection Data}

We interpret the seismic stratigraphy of a structurally undeformed reach of an upper Miocene (calcareous nannofossil zone CN7, 10.55-9.53 Ma; Gradstein et al., 2012) submarine channel system in the Lower Congo Basin, offshore Angola (Da Costa et al., 2001; Fig. 1). The seismic reflection volume has a dominant frequency of $30 \mathrm{~Hz}, 12.5 \mathrm{~m}$ horizontal sampling rate, and is zero-phase. Two-way traveltime (TWTT) is con- verted to depth assuming an average velocity of $2700 \mathrm{~m} / \mathrm{s}$ based on well to seismic ties. We interpreted seismic horizons on the $5^{\circ}-20^{\circ}$ angle stack.
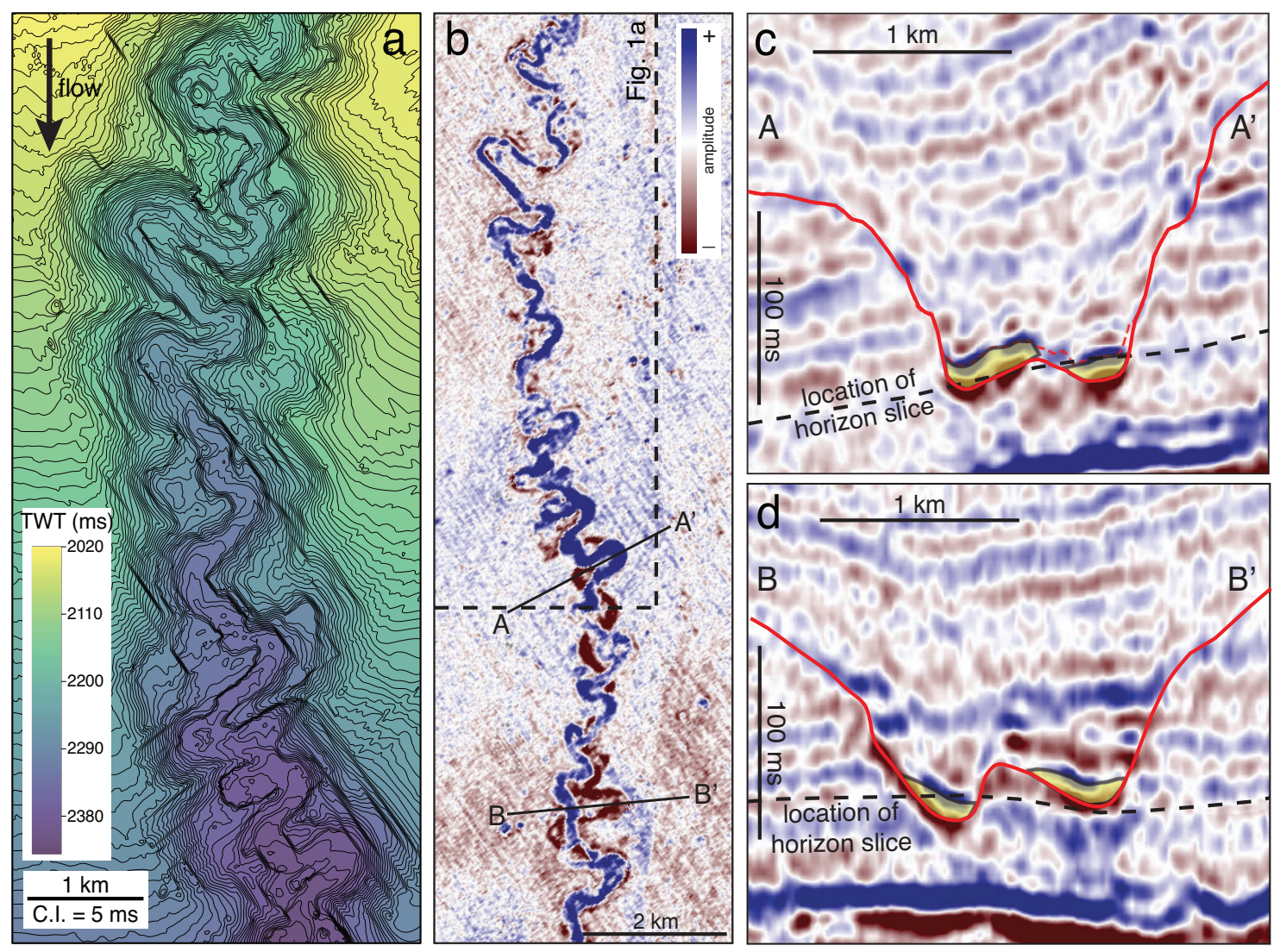

Figure 1: A: Topography of basal erosional surface of submarine channel offshore Angola. Area is located between $5^{\circ} 24^{\prime} \mathrm{S}$ and $6^{\circ} 01^{\prime} \mathrm{S}$, and $10^{\circ} 56^{\prime} \mathrm{E}$ and $11^{\circ} 37^{\prime} \mathrm{E}$. TWTT - two-way traveltime; c.i. - contour interval. B: Seismic horizon slice showing high-amplitude channel remnants on the valley sides, above the continuous channel thread. C, D: Cross sections illustrating the typical distribution of sand bodies in the valley.

\section{Numerical Modeling}

The prominent geomorphologic and stratigraphic features of the submarine channel offshore Angola are captured in a numerical model that we developed based on the Howard and Knutson (1984) meandering model (HK; for details of model implementation, see the Supplementary Materials). This model assumes constant channel width, and bank erosion is driven by channel curvature, integrated over a segment upstream from the point where the calculation is performed. The HK model has been successfully used in modeling subaerial meander development (e.g., Finnegan and Dietrich, 2011; Limaye and Lamb, 2014). 

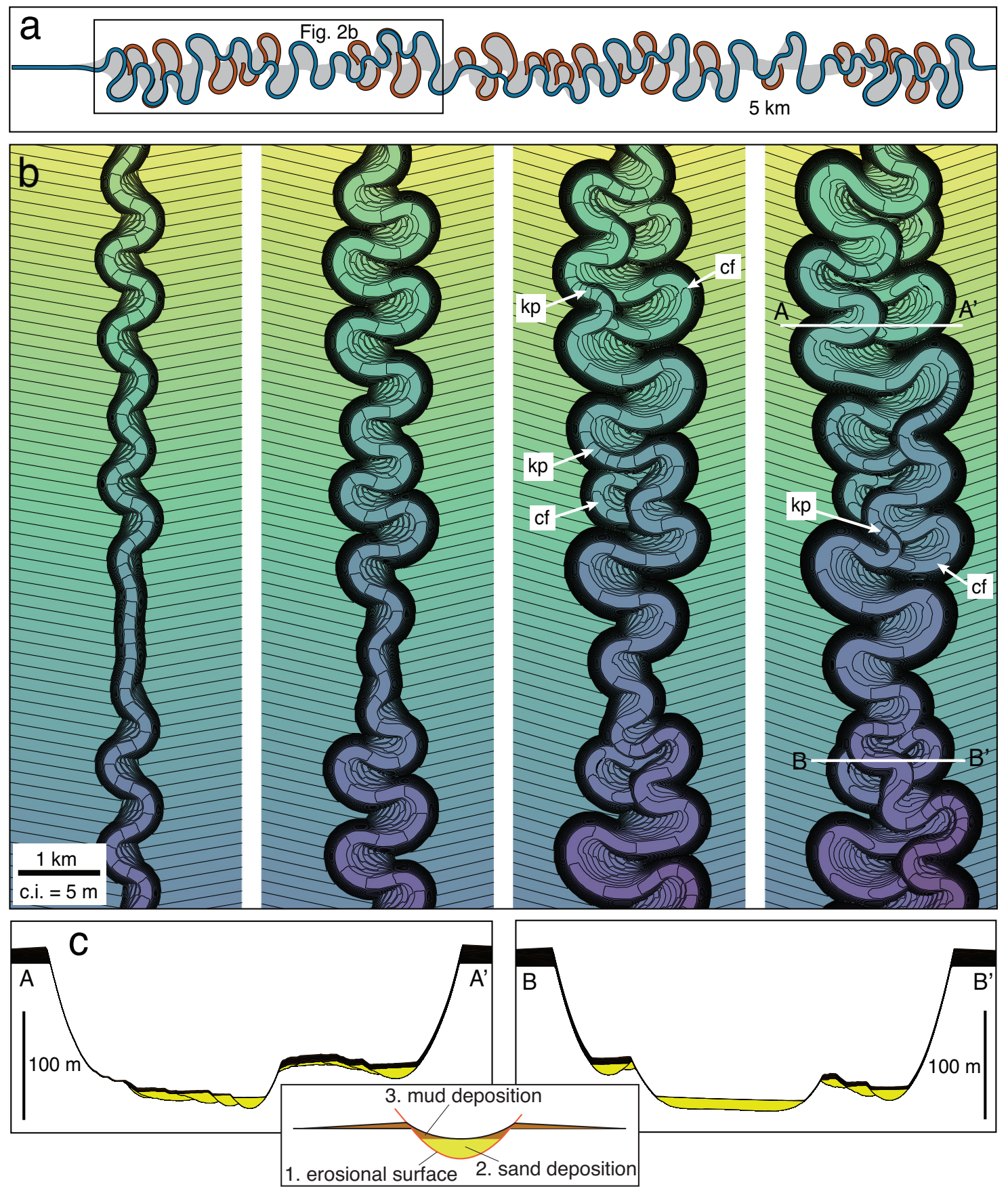

Figure 2: Results from the modified Howard and Knutson (1984) model. A: Planform expres- sion of channel system; the most recent channel location is highlighted in blue and cutoffs are shown in brown. B: Topographic surface through time. A few cutoffs (cf) and the related knickpoints (kp) are highlighted (c.i.- contour interval). C, D: Cross sections illustrating the distribution of sand in the model and the disconnect between hanging cutoffs and basal channel thread. Inset below $\mathrm{C}$ and $\mathrm{D}$ shows how surfaces (erosion, sand deposition, and mud deposition) were created around each centerline. 
More sophisticated physics-based models have been developed for turbidity currents that shape submarine channels (e.g., Das et al., 2004); however, the HK model has the advantage of simpler input parameter choice and lower computational complexity. The HK model does not cover the full spectrum of submarine channel behavior. For example, turbidity currents that are not in equilibrium with their containing channel can deposit sediment closer to the outer bank (Kane et al., 2008; Jobe et al., 2015). Our goal here is to investigate the larger scale stratigraphic implications of relatively simple early sinuosity development that is coupled with incision.

Many models of channel meandering assume constant slope along the centerline (Ikeda et al., 1981; Howard and Knutson, 1984; Sun et al., 1996). However, channel slope variability and knickpoint dynamics are likely to be important factors in the long-term evolution of submarine channels (Pirmez et al., 2000; Mitchell, 2006; Heinio and Davies, 2007). Therefore, in a manner similar to that of Finnegan and Dietrich (2011), we track the vertical coordinate of the channel centerline. Incision is modeled as a function of the boundary shear stress (Howard and Kerby, 1983), which varies with the channel gradient. The channel centerlines generated with the HK model provide the framework for our simulations. To examine the resulting geomorphology we created geomorphic surfaces that mimic realistic channel morphologies at each time step (e.g., Sylvester et al., 2011). To simulate erosion, we used a cross section with a quadratic shape; then coarse-grained channel deposition is modeled with partially filling the channel to a fraction of the channel depth (Fig. 2). Although real-world channel deposits have significantly more complicated geometries, it is likely that this detail does not affect the large-scale structure of the resulting stratigraphy. The third and final surface corresponds to overbank deposition; it is generated as a muddy layer that linearly thins away from the channel (Fig. 2).

\section{Results}

\section{Seismic Stratigraphy and Channel Morphology}

The seismic stratigraphy of the studied channel system comprises high-amplitude seismic reflections organized into discontinuous loops (i1000 m long, i400 m wide), and a single high- amplitude, sinuous ribbon with similar widths and a mean half-wavelength sinuosity of 1.5 that is continuous downstream and has been mapped for more than $23 \mathrm{~km}$ (Fig. 1). These high-amplitude seismic reflections are overlain by lower amplitude sheets, which drape or lap onto a large-scale (;200 ms TWTT relief) erosional surface. The high-amplitude, discontinuous loops also terminate against this erosional surface, and they are located in an elevated position, above the high-amplitude ribbon at the base of the system. Gamma-ray wireline logs that penetrate the high-amplitude seismic reflections exhibit low values, suggesting high sand content; high gamma-ray values from the lower amplitude sheets are evidence for their predominantly muddy character. The sands deposited in the most recent and best-preserved channel thalweg are coarse grained and poorly sorted, and therefore have a high impedance compared to the surrounding mudstones. Based on well to seismic ties, the top of this sandstone corresponds to peaks. The disconnected loops are remnant channel deposits in terraces that were cut off and truncated against the more continuous channel deposits; the latter correspond to a single ribbon in the thalweg of the youngest large-scale channel-form surface. The width and sinuosity of individual ribbons of high-amplitude seismic reflections, showing cutoff meanders similar to features of subaerial floodplains, are consistent with other seismically imaged submarine channel deposits (Normark et al., 1993; Deptuck et al., 2003). The lower amplitude reflections represent hemipelagic mud drape and overbank deposits adjacent to channel forms.

This stratigraphic structure suggests an early channel evolution dominated by the development of an actively meandering channel that carves a broad erosional valley and truncates its own cutoff deposits as it incises. With a few exceptions, these deposits do not show evidence for gradual growth of channel bends. 


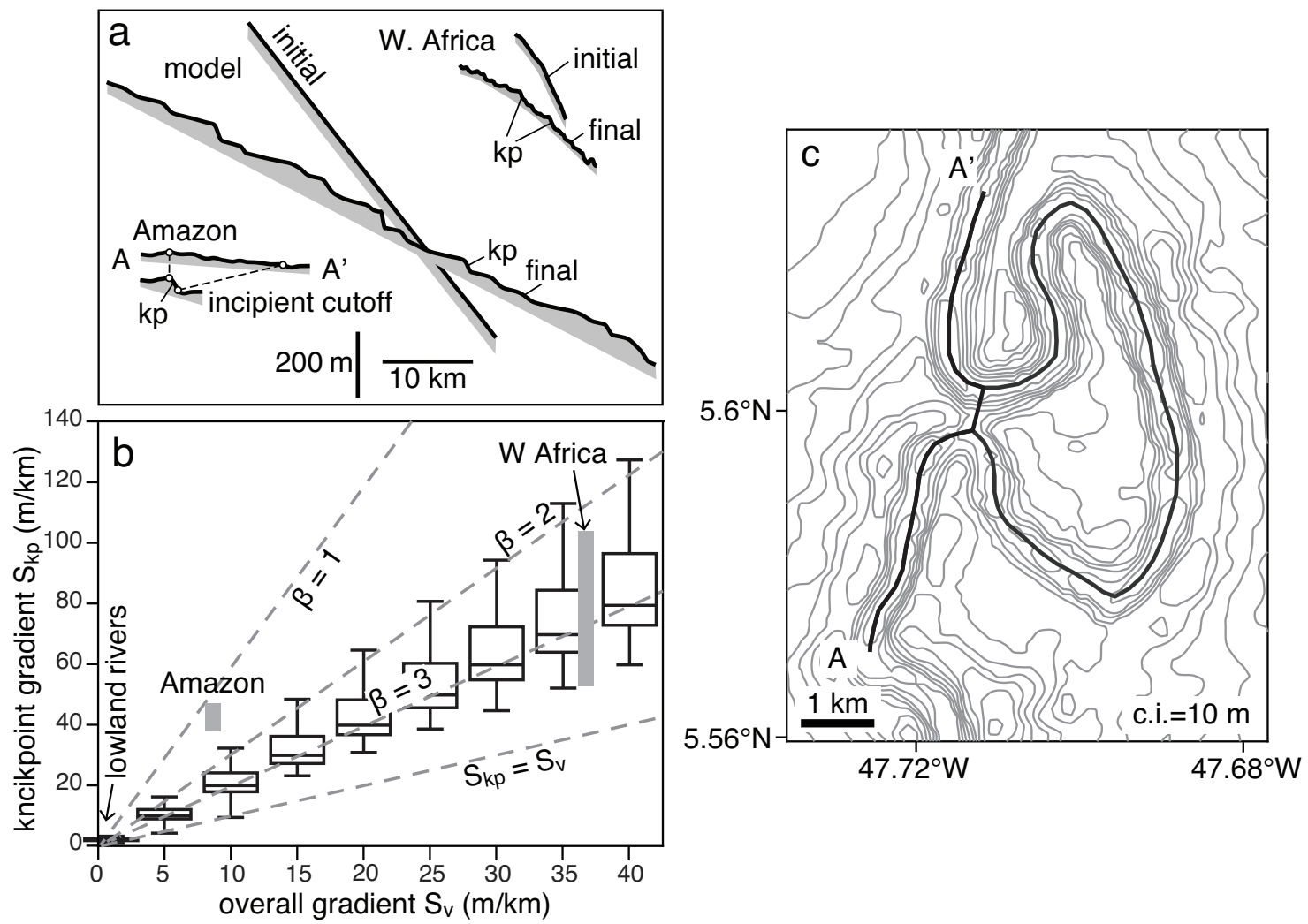

Figure 3: A: Comparison of initial and final model profiles (center) with similar profiles estimated from seismic reflection data from offshore Angola (upper right); bathymetric profiles along an incipient cutoff meander on the Amazon Channel (lower left; kp - knickpoint). B: Plot of knickpoint gradients as a function of overall (valley) gradients $(\mathrm{Sv})$, assuming variable cutoff distances $(=1,2,3$, where is the ratio between cutoff distance and channel width). Boxplots show the variability of cutoff slopes in multiple simulations for the $=3$ case. Gradients characteristic of lowland rivers, the Amazon Channel (Pirmez and Imran, 2003), and steep submarine channels (this study) are displayed as gray bars. C: Bathymetric map of an incipient cutoff on the Amazon Channel. Black lines show locations of the two bathymetric profiles shown in A. Created from SeaBeam bathymetry data (Pirmez and Flood, 1995) (c.i.-contour interval).

\section{Numerical Model}

In the meandering channel model, the gradual development of sinuosity broadens the valley but reduces the along-channel gradients (Figs. 2 and 3; Movies DR1 and DR2 in the Data Repository). As meander bends reach maturity at roughly the same time, the first wave of cutoffs forms in a relatively short time period; and as the active channel thalweg incises, the cutoffs are left behind as terraces hanging above the valley floor (Fig. 2). The appearance of cutoffs also leads to a quick transition of the initially smooth along-channel profile to one with significant variability in gradients, and variable incision rates. The initial length of the cutoff-related knickpoints is related to the threshold distance over which cutoffs are set to occur in the model. The elevation drop over the cutoff location is related to the initial slope; with a gradient of $36 \mathrm{~m} / \mathrm{km}$, the average relief of the knickpoints is $25 \mathrm{~m}$ and the mean gradient is $83 \mathrm{~m} / \mathrm{km}$ or $4.75^{\circ}$. These values are similar to those observed in the example from Angola (Fig. 3B). 


\section{Discussion}

Most of the model features described here are also characteristic of the seismic reflection example from Angola, i.e., truncated and hanging cutoff bends surround a continuous channel ribbon that corresponds to the youngest location of the active channel (Fig. 1). In sections where cutoffs have occurred, the valley is broad and flat-based; in sections unaffected by cutoffs, the valley is narrow and has strongly asymmetric cross sections, with long and narrow ridges in the inner bank region of the bends. These observations are consistent with the geometries of the model and the idea that this system represents an early stage of channel evolution, when not all initial channel bends have gone through the cutoff process. Although the initial channel form is not preserved in the subsurface example, we can estimate the original along-channel slope profile by looking at a dip section outside of the erosional valley (Fig. 3A). The transition from this smooth and steep profile to one with significant irregularities and knickpoints along the youngest channel thalweg is similar to the one observed in the numerical model. The largest elevation changes in the final channel profile are similar in scale to well-imaged knickpoints in other submarine channels (e.g., Heinio and Davies, 2007; Amazon Channel, Fig. 3C). The knickpoint gradients are significantly larger than the initial (valley) gradient Sv, and they increase with increasing values of $\mathrm{Sv}$ and with decreasing values of the dimensionless cutoff distance (the ratio between cutoff distance and channel width) (Fig. 3B).

Apart from the example shown here, many early-stage submarine channels have a single, well-defined, sinuous, high-amplitude ribbon at their base, with limited or no evidence for bend growth and sinuosity development (Gee et al., 2007; Deptuck et al., 2012; Kolla et al., 2012; Fildani et al., 2013). It has been suggested that early submarine channel sinuosity might be a result of processes other than centrifugal instability and bank retreat, such as preexisting topographic and/or structural influence (Kolla et al., 2001, 2007). Our observations suggest that high channel incision rates are responsible for the lack of depositional evidence for lateral bend growth and downstream channel translation. Natural incision rates are potentially even higher, relative to lateral migration rates, than those used to generate the model shown here, as some inner bank deposits are still preserved in the model to a degree larger than suggested by the seismic reflection data (Figs. 2C and 2D). Submarine channel-bend cutoffs are common in other high-sinuosity submarine channel systems (Heinio and Davies, 2007; Kolla et al., 2012; Babonneau et al., 2004; Jobe et al., 2015). Development and maintenance of high sinuosity is associated with cutoffs; the longer the time of active channel evolution, the larger must be the number of cutoff bends and associated knickpoints. Although our focus here is on incisional systems, cutoffs and related knickpoints must exist in aggradational channel belts as well, and the model presented here can be adapted to aggradational scenarios with minor modifications.

\section{Conclusions}

Knickpoint-driven incision and preservation of unpaired bedrock terraces and cutoffs has been documented and modeled in subaerial bedrock channels (Finnegan and Dietrich, 2011). These processes and products might be even more common in submarine channels than bedrock rivers, as a result of overall more erodible, mud-rich substrates on continental margins and a better preservation of meandering geometries due to lack of precipitation-driven erosion. Our modeling and field observations suggest that (1) development of sinuosity during incision results in poorly preserved inner bend deposits and hanging cutoffs that are disconnected from the most recent channel thalweg; and (2) steep cutoff-related knickpoints with gradients of 40-100 $\mathrm{m} / \mathrm{km}$ lead to a significant variability of otherwise smooth submarine channel gradients. In addition to the previously documented knickpoint-generating processes of avulsion (Pirmez et al., 2000) and structural deformation (Heinio and Davies, 2007), cutoff-related knickpoints are probably common features of most submarine channels with high sinuosities. This is a process that is likely to affect both the mor- phology and stratigraphy of submarine channel deposits, without any influence of external fac- tors, as it has the potential to result in incisions several tens of meters deep into already deposited channel sediments. It also might be one of the reasons why the stratigraphic architecture of submarine channel deposits is significantly more complicated than implied by simple stratigraphic models assuming constant along-chan- nel slope (e.g., Sylvester et al., 2011). 
Discontinuities in submarine channel morphology and stratigraphy, such as incisions of different scales, knickpoints, and terraces, are commonly interpreted as the result of external forcing (e.g., Posamentier and Kolla, 2003; Mayall et al., 2006). We suggest that the autogenic processes of channel bend growth and cutoff formation can lead to numerous morphologic and stratigraphic discontinuities, without changes in sea level or climate, and without structural deformation or major avulsions.

We have shown here that cutoff-related knickpoint development must be common in submarine channels with high sinuosity. More work is needed to better constrain erosion rates and the impact of the related erosion and deposition on the stratigraphic record. These processes inform the interpretation of continental margin stratigraphic evolution and have implications for the architecture of hydrocarbon reservoirs.

\section{Acknowledgements}

We are grateful for help from and discussions with Morgan Sullivan, Richard Sech, Tao Sun, Kaveh Gayour, Alicia Kahn, David Grimes, Nick Drinkwater, Nick Howes, and Zane Jobe, and for the permission to publish by Chevron Energy Technology Company. Covault acknowledges support of the sponsors of the Quantitative Clastics Laboratory (http://www.beg.utexas.edu/indassoc/dm2/). The paper has benefited from careful and constructive reviews by Joris Eggenhuisen, Ian Kane, Neil Mitchell, and editorial comments by James Schmitt.

\section{References}

[1] Babonneau, N., Savoye, B., Cremer, M., and Bez, M., 2004, Multiple terraces within the deep incised Zaire Valley (ZaiAngo Project): Are they confined levees?, in Lomas, S.A., and Joseph, P., eds., Confined turbidite systems: Geological Society of London Special Publication 222, p. 91-114, doi:10.1144/GSL.SP.2004.222.01.06.

[2] Clift, P., and Gaedicke, C., 2002, Accelerated mass flux to the Arabian Sea during the middle to late Miocene: Geology, v. 30, p. 207-210, doi:10.1130 /0091-7613(2002)030<0207:AMFTTA>2.0.CO;2.

[3] Covault, J.A., Romans, B.W., Fildani, A., McGann, M., and Graham, S.A., 2010, Rapid climatic signal propagation from source to sink in a southern California sediment-routing system: Journal of Geology, v. 118, p. 247-259, doi:10.1086/651539.

[4] Da Costa, J.L., Schirmer, T.W., and Laws, R.B., 2001, Lower Congo Basin, deep-water exploration province, offshore West Africa, in Downey, M.W., et al., eds., Petroleum provinces of the twentyfirst century: American Association of Petroleum Geologists Memoir 74, p. 517-530.

[5] Das, H.S., Imran, J., Pirmez, C., and Mohrig, D., 2004, Numerical modeling of flow and bed evolution in meandering submarine channels: Journal of Geo- physical Research, v. 109, C10009, doi:10.1029/2002JC001518.

[6] Deptuck, M.E., Steffens, G., Barton, M.D., and Pir- mez, C., 2003, Architecture and evolution of upper fan channel-belts on the Niger Delta slope and in the Arabian Sea: Marine and Petroleum Geology, v. 20, p. 649-676, doi:10.1016/j .marpetgeo.2003.01.004.

[7] Deptuck, M.E., Sylvester, Z., and O'Byrne, C., 2012, Pleistocene seascape evolution above a "simple" stepped slope-Western Niger Delta, in Prather, B.E., et al., eds., Application of the principles of seismic geomorphology to continental-slope and base-of-slope systems: Case studies from seafloor and near-seafloor analogues: SEPM (Society for Sedimentary Geology) Special Publication 99, p. 199-222, doi:10.2110/pec.12.99.0199.

[8] Fildani, A., Hubbard, S.M., Covault, J.A., Maier, K.L., Romans, B.W., Traer, M., and Rowland, J.C., 2013, Erosion at inception of deep-sea channels: Marine and Petroleum Geology, v. 41, p. 48-61, doi:10.1016/j.marpetgeo.2012.03.006. 
[9] Finnegan, N.J., and Dietrich, W.E., 2011, Episodic bedrock strath terrace formation due to meander migration and cutoff: Geology, v. 39, p. 143-146, doi:10.1130/G31716.1.

[10] Gee, M., Gawthorpe, R., Bakke, K., and Friedmann, S., 2007, Seismic geomorphology and evolution of submarine channels from the Angolan continental margin: Journal of Sedimentary Research, v. 77, p. 433-446, doi:10.2110/jsr.2007.042.

[11] Gradstein, F.M., Ogg, J.G., Schmitz, M., and Ogg, G., 2012, The geologic time scale 2012: Amsterdam, Elsevier, $1176 \mathrm{p}$.

[12] Heinio, P., and Davies, R.J., 2007, Knickpoint migra- tion in submarine channels in response to fold growth, western Niger Delta: Marine and Petro- leum Geology, v. 24, p. 434-449, doi:10.1016/j.marpetgeo.2006.09.002.

[13] Howard, A.D., and Kerby, G., 1983, Channel changes in badlands: Geological Society of America Bulletin, v. 94, p. 739-752, doi:10.1130/0016-7606 (1983)94<739:CCIB >2.0.CO;2.

[14] Howard, A.D., and Knutson, T., 1984, Sufficient condi- tions for river meandering: A simulation approach: Water Resources Research, v. 20, p. 1659-1667, doi:10.1029/WR020i011p01659.

[15] Ikeda, S., Parker, G., and Sawai, K., 1981, Bend theory of river meanders. Part 1: Linear development: Journal of Fluid Mechanics, v. 112, p. 363-377, doi:10.1017/S0022112081000451.

[16] Jobe, Z.R., Sylvester, Z., Parker, A.O., Howes, N., Slowey, N., and Pirmez, C., 2015, Rapid adjust- ment of submarine channel architecture to changes in sediment supply: Journal of Sedimentary Research, v. 85, p. 729-753, doi:10.2110/jsr.2015.30.

[17] Kane, I.A., McCaffrey, W.D., and Peakall, J., 2008, Controls on sinuosity evolution within submarine channels: Geology, v. 36, p. 287-290, doi: 10.1130/G24588A.1.

[18] Kolla, V., Bourges, P., Urruty, J., and Safa, P., 2001, Evolution of deep-water Tertiary sinuous chan- nels offshore Angola (West Africa) and implications for reservoir architecture: American Association of Petroleum Geologists Bulletin, v. 85, p. 1373-1405, doi:10.1306/8626CAC3-173B-11D7$8645000102 \mathrm{C} 1865 \mathrm{D}$.

[19] Kolla, V., Posamentier, H., and Wood, L.J., 2007, Deep-water and fluvial sinuous channels: Characteristics, similarities and dissimilarities, and modes of formation: Marine and Petroleum Geology, v. 24, p. 388-405, doi:10.1016/j.marpetgeo.2007.01.007.

[20] Kolla, V., Bandyopadhyay, A., Gupta, P., Mukherjee, B., and Ramana, D.V., 2012, Morphology and internal structure of a recent upper Bengal Fan-valley complex, in Prather, B.E., et al., eds., Application of the principles of seismic geomorphology to continental-slope and base-of-slope systems: Case studies from seafloor and near-seafloor analogues: SEPM (Society for Sedimentary Geology) Special Publication 99, p. 347-369, doi:10.2110/pec.12.99.0347.

[21] Limaye, A.B.S., and Lamb, M.P., 2014, Numerical simulations of bedrock valley evolution by meandering rivers with variable bank material: Journal of Geophysical Research, v. 119, p. 927-950, doi: 10.1002/2013JF002997.

[22] Mayall, M., Jones, E., and Casey, M., 2006, Turbidite channel reservoirs — Key elements in facies prediction and effective development: Marine and Petroleum Geology, v. 23, p. 821-841, doi:10.1016/j.marpetgeo.2006.08.001.

[23] McHargue, T.R., Pyrcz, M.J., Sullivan, M.D., Clark, J.D., Fildani, A., Romans, B.W., Covault, J.A., Levy, M., Posamentier, H., and Drinkwater, N., 2011, Architecture of turbidite channel systems on the continental slope: Patterns and predictions: Marine and Petroleum Geology, v. 28, p. 728- 743, doi:10.1016/j.marpetgeo.2010.07.008. 
[24] Mitchell, N., 2006, Morphologies of knickpoints in submarine canyons: Geological Society of America Bulletin, v. 118, p. 589-605, doi:10.1130 /B25772.1.

[25] Normark, W.R., Posamentier, H., and Mutti, E., 1993, Turbidite systems: State of the art and future directions: Reviews of Geophysics, v. 31, p. 91-116, doi:10.1029/92RG02832.

[26] Pirmez, C., and Flood, R., 1995, Morphology and structure of Amazon Channel, in Flood, R.D., et al., Proceedings of the Ocean Drilling Program, Initial reports, Volume 155: College Station, Texas, Ocean Drilling Program, p. 23-45, doi:10.2973/odp.proc.ir.155.103.1995.

[27] Pirmez, C., and Imran, J., 2003, Reconstruction of turbidity currents in Amazon Channel: Marine and Petroleum Geology, v. 20, p. 823-849, doi: 10.1016/j.marpetgeo.2003.03.005.

[28] Pirmez, C., Beaubouef, R., Friedmann, S., and Mohrig, D., 2000, Equilibrium profile and baselevel in submarine channels: Examples from late Pleisto- cene systems and implications for the architecture of deepwater reservoirs, in Deep-water reservoirs of the world: Gulf Coast Section, SEPM (Society for Sedimentary Geology) Foundation 20th Annual Research Conference, p. 782-805, doi:10.5724/gcs.00.15.0782.

[29] Posamentier, H.W., and Kolla, V., 2003, Seismic geomorphology and stratigraphy of depositional elements in deepwater settings: Journal of Sedimentary Research, v. 73, p. 367-388, doi:10.1306/111302730367.

[30] Snedden, J.W., 2013, Channel-body basal scours: Observations from 3D seismic and importance for subsurface reservoir connectivity: Marine and Petroleum Geology, v. 39, p. 150-163, doi:10.1016/j.marpetgeo.2012.08.013.

[31] Sun, T., Meakin, P., Jøssang, T., and Schwarz, K., 1996, A simulation model for meandering rivers: Water Resources Research, v. 32, p. 2937-2954, doi:10.1029/96WR00998.

[32] Sylvester, Z., Pirmez, C., and Cantelli, A., 2011, A model of submarine channel-levee evolution based on channel trajectories: Implications for stratigraphic architecture: Marine and Petroleum Geology, v. 28, p. 716-727, doi:10.1016/j.marpetgeo.2010.05.012.

[33] Talling, P.J., et al., 2015, Key future directions for research on turbidity currents and their deposits: Journal of Sedimentary Research, v. 85, p. 153-169, doi:10.2110/jsr.2015.03.

\section{Supplementary Materials}

\section{Animations from Numerical Model}

- Animation of incising sinuous submarine channel, 3D view - available at https://doi.org/10.6084/ m9.figshare.5552755.v3

- Animation of changes in along-channel slope profile during incision - available at https://doi.org/ 10.6084/m9.figshare.5552773.v1

- Animation of incising sinuous submarine channel with cutoffs, plan view - available at https://doi. org/10.6084/m9.figshare.5552776.v1 


\section{Description of Numerical Model}

The Howard and Knutson (1984) model was implemented using the open-source Jupyter / IPython Notebook computing platform (Pérez and Granger, 2007), with scripts written in the Python programming language.

The HK model is based on the calculation of an adjusted channel migration rate R1 from a nominal migration rate $R_{0}$, using a weighting function $G(\xi)$ :

$$
R_{1}(s)=\Omega R_{0}(s)+\left(\Gamma \int_{0}^{\infty} R_{0}(s-\xi) G(\xi) d \xi\right)\left(\int_{0}^{\infty} G(\xi) d \xi\right)^{-1}
$$

where $R_{0}(s)$ and $R_{0}(s-\xi)$ are the nominal migration rates at locations $s$ and at a distance $\xi$ upstream from $s$, respectively. $\Omega$ and $\Gamma$ are weighting parameters that are set to -1 and 2.5 respectively, to produce one of the two parameterizations of stable meandering (Howard and Knutson, 1984). $G(\xi)$ is a weighting function that decreases exponentially in the upstream direction:

$$
G(\xi)=e^{-\alpha \xi}
$$

The value of the parameter $\alpha$ determines how fast the upstream influence declines; and it is calculated as

$$
\alpha=2 k C_{f} / D
$$

where $k$ is a scaling parameter of the order of unity for rivers, $D$ is channel depth, and $C_{f}$ is the coefficient of friction (Howard and Knutson, 1984). In theory, one could estimate the values of $k$ and $C_{f}$ for submarine channels and use these to calculate the parameter $\alpha$. However, using $k=1$ (Howard and Knutson, 1984) and $C_{f}=0.005$, a value commonly used for turbidity currents (Komar, 1975; Pirmez and Imran, 2003; Konsoer et al., 2013), with reasonable values for channel depth, gives relatively small values of $\alpha$ that translate into a slowly decreasing weighting function and a far-reaching upstream influence. This in turn results in a characteristic wavelength that is significantly larger than what is expected in the case of rivers and submarine channels. Therefore, we have tuned the parameters in equation (3) so that the wavelength-width relationship is similar to what has been documented in nature (e.g., Pirmez and Imran, 2003). A comparable approach - tuning the parameters so that the desired wavelength is obtained - has been adopted by Finnegan and Dietrich (2011) as well.

The nominal and actual migration rates are computed from curvature, which in turn is calculated from the Cartesian coordinates of the channel centerline:

$$
\eta=\frac{x^{\prime} y^{\prime \prime}-y^{\prime} x^{\prime \prime}}{\left(x^{\prime 2}+y^{\prime 2}\right)^{3 / 2}}
$$

where $x^{\prime}$ and $x^{\prime \prime}$ denote first and second derivatives of the $x$ coordinate. To model the dependence of migration rate on curvature, we have adopted the functions used by Finnegan and Dietrich (2011):

$$
\begin{gathered}
R / W<=C^{*}, R_{0}=k_{l} R / W, \\
R / W>C^{*}, R_{0}=k_{l} C^{* 2} W / R,
\end{gathered}
$$

where $R$ is radius of curvature, $W$ is channel width, $C^{*}$ is a critical value of $R / W$ (which equals $1 / \eta W$, that is, the inverse of the dimensionless curvature), and $k_{l}$ is the lateral migration rate constant. We have used $C^{*}=2.0$; this is different from the 5.0 value used by Finnegan and Dietrich (2011), but reasonable taking into account that the resulting actual migration rates match relatively well the river data of Nanson and Hickin (1986) (Fig. DR1), and the resulting channel bend shapes are similar to those observed in the seismic data.

We used a lateral erosion rate constant of $3.17 \times 10^{-8} \mathrm{~m} / \mathrm{s}$ (or $2 \mathrm{~m} /$ year). This results in actual migration rates of up to $2.7 \mathrm{~m} /$ year. These values are relatively large, but not uncommon in rivers (e.g., Nanson and Hickin, 1986; Constantine et al., 2014); and the few observations from modern submarine channels and canyons suggest that such high lateral migration rates may be characteristic of active deepwater systems (Conway et al., 2012; Biscara et al., 2013). 


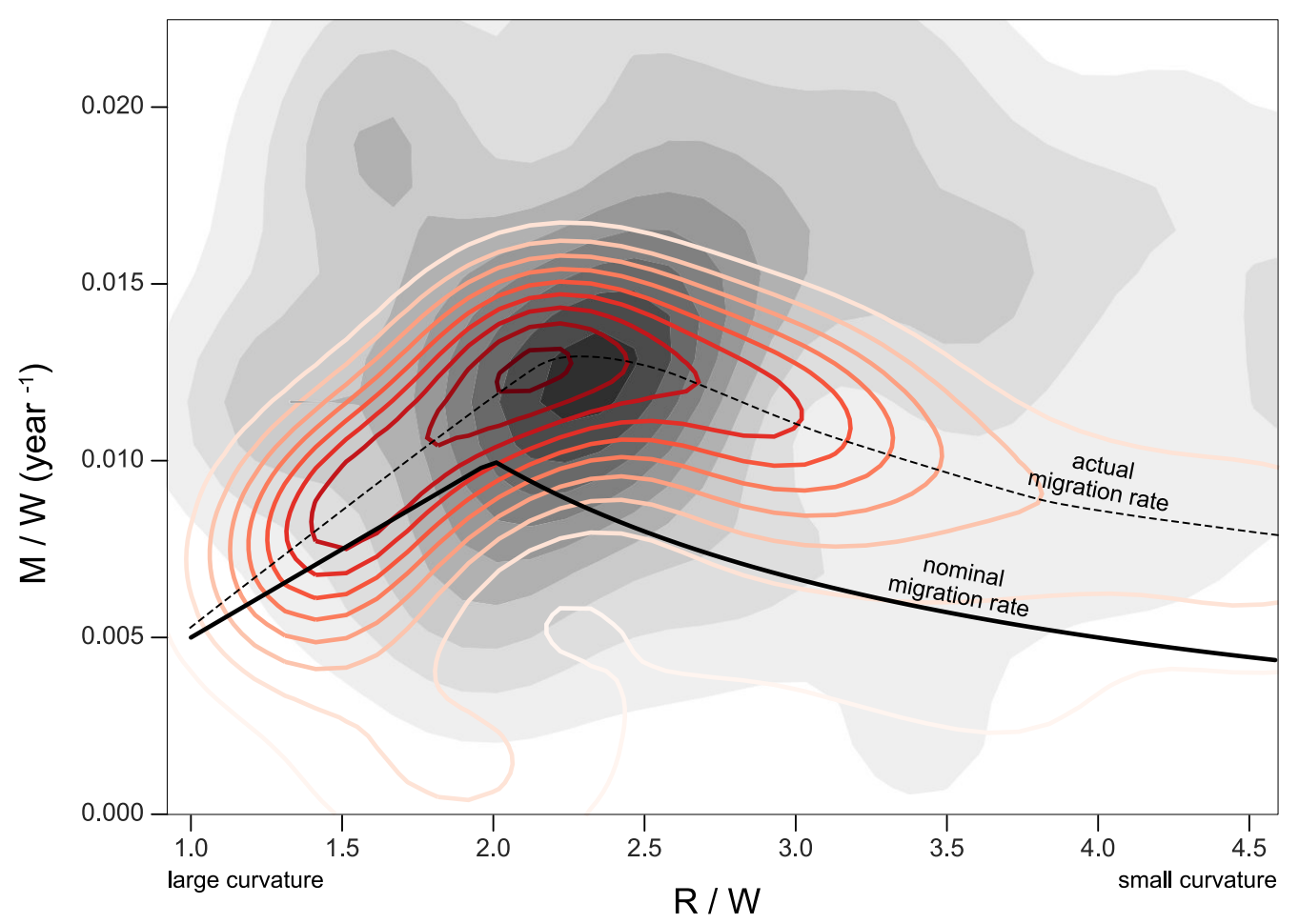

Figure 4: Plot of nominal (continuous line) and actual (dashed line and red density contours) normalized migration rates $(M / W)$ against $R / W$, computed for one channel centerline in the HK model, with $k_{l}=$ $1.59 \times 10^{-8} \mathrm{~m} / \mathrm{s}$. River data points $(\mathrm{n}=191)$ from Nanson and Hickin $(1986)$ are shown as grey density map in background.

For modeling vertical incision, we use the simplest erosion law that relates vertical incision rate to mean shear stress acting on the channel thalweg (Finnegan and Dietrich, 2011):

$$
v=k_{v} \sigma_{b},
$$

where $\sigma_{b}$ is the bed shear stress and $k_{v}$ is a vertical erosion rate constant. For turbidity currents in a submarine channel, the driving force for a volume of fluid of length is

$$
F=\rho R C L g A S,
$$

where $\rho$ is density of seawater, $R$ is the excess sediment density, $C$ is flow concentration, $A$ is the cross sectional area of the flow, and $S$ is slope (e.g., Konsoer et al., 2013). In the case of steady and uniform flow the shear stresses on the bottom and top of the current balance this force; assuming that channel depth is small compared to channel width, this balance can be written as

$$
\sigma_{b}+\sigma_{i}=\rho R C g D S,
$$

where $D$ is flow depth and $\sigma_{i}$ is the shear stress at the top of the flow. Using $\sigma_{i}=r \sigma_{b}$, we get

$$
v=k_{v} \rho \operatorname{RCg} D S /(1+r) .
$$

Assuming a sediment concentration of 0.01 and an $r$ value of 0.5 (e.g., Komar, 1975), we find that a vertical slope-dependent erosion rate constant of $3.76 \times 10^{-10} \mathrm{~Pa}^{-1} \mathrm{~ms}^{-1}$ translates to about $0.42 \mathrm{~m} /$ year erosion 
for the initial slope of 0.036 . Because the channel slope decreases as sinuosity develops, this relatively large value drops to about $0.1 \mathrm{~m} /$ year for typical slopes that characterize the sinuous channels in the model. At knickpoint locations slopes are steeper and the rate of incision can be as high as $1.5 \mathrm{~m} /$ year. Overall, the incision rates in the model are about an order of magnitude smaller than the lateral migration rates. These values are highly speculative, as data on typical turbidity current concentrations and incision rates is extremely limited. For example, it is possible that erosion is a nonlinear function of slope and it only takes place at quickly migrating knickpoints.

We also need to consider that turbidity currents in submarine channels only last for a few hours or days; therefore, these estimates for erosion rates and shear stresses are long-term averages and erosion rates

during individual events must be one or two orders of magnitude larger. Repeat bathymetric surveys of active systems suggest that channel erosion can be surprisingly extensive and fast and these long-term and short-term incision rates are not unreasonable (Conway et al., 2012; Biscara et al., 2013). Furthermore, the overall morphology and stratigraphy of the modeled channel system does not depend on the exact values of the erosion rates; instead, they are driven by the relative magnitudes of the lateral and vertical rates of movement.

For the model illustrated here, we used a channel width of $100 \mathrm{~m}$, channel depth of $5 \mathrm{~m}$, and time step of $12.6 \times 10^{6} \mathrm{~s}$ (145.8 days). We saved every $100^{t h}$ resulting channel centerline. The initial distance between the points that define the channel was set to $50 \mathrm{~m}$; this distance was kept approximately constant during the simulation by resampling using a parametric spline representation of the curve (Güneralp and Rhoads, 2008). Centerlines were smoothed using a Savitzky-Golay filter (Savitzky and Golay, 1964) in every time step. The initial gradient was set to $36 \mathrm{~m} / \mathrm{km}$, similar to the value estimated for the West Africa example. The meander cutoff threshold was set to three times the channel width; however, a cutoff bend distance of two channel widths gives realistic looking results as well. Although not much is known about the dynamics of cutoffs in submarine channels, the shapes of the cutoff bends in the seismic data used here and in other data volumes (e.g., Deptuck et al., 2007) suggest that cutoff formation can take place at relatively large distances between channel bends. Early cutoff formation in submarine channels could be related to times when the channel undergoes significant filling so that its relief is less prominent ('pseudo meander cutoffs', Deptuck et al., 2007). On the other hand, the incipient cutoff on the Amazon Channel (Fig. 3c) suggests that neck cutoffs with cutoff distances close to one channel width can develop as well.

\section{References}

[1] Biscara, L., Mulder, T., Hanquiez, V., Marieu, V., Crespin, J.-P., Braccini, E., and Garlan, T., 2013, Morphological evolution of Cap Lopez Canyon (Gabon): Illustration of lateral migration processes of a submarine canyon: Marine Geology, v. 340, p. 49-56, doi: 10.1016/j.margeo.2013.04.014.

[2] Constantine, J.A., Dunne, T., Ahmed, J., Legleiter, C., and Lazarus, E.D., 2014, Sediment supply as a driver of river meandering and floodplain evolution in the Amazon Basin: Nature Geoscience, v. 7, no. 12, p. 899-903, doi: 10.1038/ngeo2282.

[3] Conway, K.W., Barrie, J.V., Picard, K., and Bornhold, B.D., 2012, Submarine channel evolution: active channels in fjords, British Columbia, Canada: Geo-Marine Letters, v. 32, p. 301-312, doi: 10.1007/s00367-012-0280-4.

[4] Deptuck, M.E., Sylvester, Z., Pirmez, C., and O Byrne, C., 2007, Migration-aggradation history and 3D seismic geomorphology of submarine channels in the Pleistocene Benin-major Canyon, western Niger Delta slope: Marine and Petroleum Geology, v. 24, no. 6-9, p. 406-433.

[5] Finnegan, N.J., and Dietrich, W.E., 2011, Episodic bedrock strath terrace formation due to meander migration and cutoff: Geology, v. 39, no. 2, p. 143-146, doi: 10.1130/G31716.1. Güneralp, I., and Rhoads, B.L., 2008, Continuous Characterization of the Planform Geometry and Curvature of Meandering Rivers: Geographical Analysis, v. 40, no. 1, p. 1-25. 
[6] Howard, A.D., and Knutson, T., 1984, Sufficient Conditions for River Meandering: A Simulation Approach: Water Resources Research, v. 20, no. 11, p. 1659-1667. Komar, P.D., 1975, Supercritical flow in density currents; discussion and reply: Journal of Sedimentary Research, v. 45, no. 3, p. 747-753, doi: 10.1306/212f6e33-2b24-11d7-8648000102c1865d.

[7] Konsoer, K., Zinger, J., and Parker, G., 2013, Bankfull hydraulic geometry of submarine channels created by turbidity currents: Relations between bankfull channel characteristics and formative flow discharge: Journal of Geophysical Research-Earth Surface, v. 118, no. 1, p. 216-228, doi: 10.1029/2012JF002422.

[8] Nanson, G.C., and Hickin, E.J., 1986, A statistical analysis of bank erosion and channel migration in western Canada: Geological Society of America Bulletin, v. 97, no. 4, p. 497-504.

[9] Pérez, F., and Granger, B.E., 2007, IPython: A System for Interactive Scientific Computing: Computing in Science \& Engineering, v. 9, no. 3, p. 21-29, doi:10.1109/MCSE.2007.53.

[10] Pirmez, C., and Imran, J., 2003, Reconstruction of turbidity currents in Amazon Channel: v. 20, no. 6-8, p. 823-849.

[11] Savitzky, A., and Golay, M.J.E., 1964, Smoothing and Differentiation of Data by Simplified Least Squares Procedures, Analytical Chemistry 36 (8), p. 1627-1639, doi: 10.1021/ac60214a047. 